Abstracta Iranica Abstracta Iranica

Revue bibliographique pour le domaine irano-aryen

Volume 27 | 2006

Comptes rendus des publications de 2004

\title{
" Taxes et impôts dans le sud de la Palestine (IVe s. av. J.-C.) ». Transeuphratène, 28 (2004), pp. 133-142.
}

\section{Astrid Nunn}

\section{(2) OpenEdition}

12 Journals

\section{Édition électronique}

URL : http://journals.openedition.org/abstractairanica/5731

DOI : 10.4000/abstractairanica.5731

ISSN : 1961-960X

Éditeur :

CNRS (UMR 7528 Mondes iraniens et indiens), Éditions de l'IFRI

\section{Édition imprimée}

Date de publication : 15 mai 2006

ISSN : 0240-8910

\section{Référence électronique}

Astrid Nunn, « « Taxes et impôts dans le sud de la Palestine (IVe s. av. J.-C.) ». Transeuphratène, 28 (2004), pp. 133-142. », Abstracta Iranica [En ligne], Volume 27 | 2006, document 87, mis en ligne le 02 janvier 2007, consulté le 25 septembre 2020. URL : http://journals.openedition.org/abstractairanica/ 5731 ; DOI : https://doi.org/10.4000/abstractairanica.5731

Ce document a été généré automatiquement le 25 septembre 2020.

Tous droits réservés 


\title{
« Taxes et impôts dans le sud de la Palestine (IVe s. av. J.-C.) ». Transeuphratène, 28 (2004), pp. 133-142.
}

\author{
Astrid Nunn
}

1 Cette étude repose sur les ostraca araméens apparus sur le marché et provenant vraisemblablement de Maqqeda/Khirbet el-Qôm. 800 de ces ostraca ont été publiés, autant doivent l'être encore. C'est leur aspect économique qui intéresse l'A., plus concrètement la collecte des taxes et impôts alimentant les caisses du Grand Roi (voir aussi J. Sapin, Trans. 27 pour la géographie politique, c.r. $n^{\circ} 103$ ). Les ostraca en effet permettent de reconstituer la collecte des taxes dans la province achéménide d'Idumée de 362-312 av. J.-C. et éclaire indirectement le fonctionnement du partenaire économique qu'était la Judée. Les taxes sont des taxes foncières, payées surtout en orge et en blé qui étaient rassemblés dans des magasins d'Idumée. Il est encore impossible de dire si un pourcentage ou une quantité fixe étaient prélevés. Temples et domaines appartenant à des prêtres semblent avoir été exemptés, comme il est souvent de coutume au Proche Orient ancien. Peut-être existait-il une taxe sur l'élevage. Dans le domaine du commerce, les achats d'esclaves et certaines personnes (capitation) étaient taxés. Le dernier prélèvement portait sur la force et le temps de travail. Cette " corvée » était utilisée pour les travaux d'intérêt public: routes, bâtiments publics, canaux... Rien pour l'instant ne montre un lien entre la perception des impôts et les temples, à l'inverse de Jérusalem où le temple était le centre de la collecte des impôts dans la province de Judée. 
INDEX

Thèmes : 3.2.1. Elam

\section{AUTEURS}

ASTRID NUNN

Université de Munich 